AGATA WESOLOWSKA

(Instytut Socjologii UMK)

\title{
PARYŻ I PARYŻANIE
}

\author{
„Paryż. I noc. I Notre Dame. \\ I wiatr. Na pustym placu sam \\ odprawia modły do Madonny (...)." \\ K. I. Gałczyński
}

\begin{abstract}
Tytuł niniejszego artykułu jest zapożyczeniem z pracy Tomasza Gobana$1 \mathrm{Klasa}^{1}$, w której autor dokonał wielostronnej i dogłębnej, a przy tym niezwykle interesujacej analizy Paryża oraz jego mieszańców. Paryż już wielokrotnie był obiektem zainteresowań naukowych, zwłaszcza historyków, historyków kultury i sztuki². Wydaje się, że powinien stać się przedmiotem dociekań również socjologów, a w szczególności socjologów miasta. Doskonale można tu bowiem obserwować zmiany, jakie zachodzą we współczesnych metropoliach, badać przebieg procesu industrializacji, mechanizmy kształtowania się wzorców stosunków społecznych, a także szeroko pojęty urbanizm, czyli to, jakie są psychologiczno-społeczne aspekty

\footnotetext{
${ }^{1}$ Wydanej w 1974 r. nakładem warszawskiej Książki i Wiedzy.

2 P. de Kock, Paryż i jego obyczaje, Warszawa 1843, t. 1-2; K. Lubczyński, Paryż-przewodnike literacko-bistoryczny, Instytut Polski, Paryż 1997 oraz Wydawnictwo UMCS, Lublin 2001; K. Pomian, Zbieracze i osobliwości, PIW, Warszawa 1996; K. Żarski, Perspektyny architektury: Warszawa, Paryż, Damaszek, AgArt, Warszawa 2001.
} 
miejskiego, a dokładnie - paryskiego - stylu życia.

Zamiarem moim było ukazanie, jaki jest Paryż i jego mieszkańcy w rzeczywistości; jak wygląda codzienne życie w jednym z najsłynniejszych miast świata, istnieją bowiem znaczne różnice w percepcji miasta przez jego stałych oraz sezonowych mieszkańców. Dla tych drugich Paryż stał się swoistym mitem, symbolem dobrobytu, odwiecznej elegancji i nieskazitelnego piękna, tymczasem nie możemy zapominać o poważnych problemach społecznych, jakie muszą dotyczyć i faktycznie dotykaja tak wielkie i różnorodne miasto. Ponadto chciałabym przedstawić dysproporcje $\mathrm{w}$ pozornie jednakowym statusie społecznym paryżanina. Interesuje mnie także kwestia oddziaływania miasta na zamieszkujące je jednostki oraz relacja odwrotna: to, w jaki sposób paryżanie w zbiorowej świadomości konstytuują swe miasto. Jakie cechy osobowościowe i społeczne pozwalają im zapewnić rozwój i ciagłą zmianę miejsca, w którym żyją, a tym samym otaczającej ich społecznej rzeczywistości.

Proponuję rozpocząć od zagadnień wkraczających w zakres zainteresowań poznawczych ekologii społecznej oraz proksemiki. Za Edwardem T. Hallem ${ }^{3}$ rozważmy przestrzeń miejska jako specyficzny twór kulturowy, w ramach którego dochodzi do interakcji pomiędzy działającymi indywiduami, przypisującymi jej znaczenie oraz przyjmującymi określone postawy emocjonalne $e^{4}$ Zauważmy, że jest to szczególne sprzężenie zwrotne, jako że struktura i charakter miasta bezpośrednio zależą właśnie od jego mieszkańców.

E. T. Hall dowodzi, że paryżanie żyją w zatłoczeniu, co zmniejsza ich fizyczny i psychiczny dystans wobec siebie. Zbyt ciasne mieszkania, zarezerwowane dla życia rodzinnego powoduja, że paryżanie chętnie spędzają czas na zewnątrz, poza domem: w restauracjach, kafejkach i bistrach. Zdaniem Halla nawet to, jakimi jeżdżą samochodami, informuje o wewnętrznych, charakterologicznych cechach paryżan. Francuskie auta sa niewielkie, funkcjonalne, a przy tym zróżnicowane: od Pegueota po Renault, świadcząc o indywidualizmie swoich użytkowników.

Paryż, podobnie jak cała Francja, przypomina gigantyczną rozgwiazdę. Do stolicy prowadzi szesnaście linii kolejowych i siedem autostrad. Mieszczą się tu dwa międzynarodowe porty lotnicze: Orly i lotnisko im. Ch. de

\footnotetext{
${ }^{3}$ E. T. Hall, Ukryty wymiar, przeł. T. Hołówka, Warszawa 1997.

${ }^{4}$ K. Olechnicki, P. Załęcki, Stownik socjologic乏ny, Graffitti BC, Toruń 1998, s. 165.
} 
Gaulle'a kolejno z 24 i 17 milionami pasażerów rocznie.

Chociaż w wyglądzie miasta przetrwały elementy szachownicy, charakterystycznej dla antycznego Rzymu ${ }^{5}$, Paryż ma układ koncentryczny. Od centrum, zamkniętego murami obronnymi wzniesionymi przez Thiersa w latach 1840-1845, a później zburzonymi, rozchodzi się krąg suburbiów i dzielnic podmiejskich, takich jak: Sarcelles, Bobigny czy Parly 2. Dalej występują cztery strefy hodowli zwierząt i upraw; pierwsza z nich obejmuje owoce, warzywa i kwiaty; druga - rośliny pastewne i bydło; kolejna - zboża, ostatnią zaś tworzą tereny leśne. Dawne uporządkowanie przestrzeni miejskiej zakłóca dziś nieregularna, przypadkowa urbanizacja wzdłuż linii komunikacyjnych. Jej kształt T. Goban-Klas porównał do rękawiczki, w której stopniowo zaludniane są przestrzenie między palcami.

Widzimy więc, że Paryż dawno przekroczył swe pierwotne granice. Czym zatem jest naprawdę? Czy traktować go jako tereny w odległości 12 $\mathrm{km}$ od Notre Dame, tradycyjnego serca miasta, włączając najbliższą strefę podmiejską i las w Boulogne? Czy też jako aglomerację paryska, rozciagająca się na odległość $18-20 \mathrm{~km}$ od słynnej świątyni? A może jest to cały region paryski, obejmujący siedem ościennych departamentów, leżący w promieniu $100 \mathrm{~km}$ od katedry? Byłby to olbrzymi obszar o jądrze w aglomeracji paryskiej i kilku mniejszych punktach koncentracji ludności. Tak więc obok Paryża-miasta z 2,2 mln mieszańców istnieje „wielki” Paryż z dziesięcioma ich milionami i wreszcie „największy” Paryż, czyli wspomniany region paryski. Intensywny rozwój miasta powoduje trudności $z$ typologia mieszkańców poszczególnych kręgów przestrzennych. Implikuje to ważkie pytanie, kogo właściwie nazwać paryżaninem?

Tradycyjnie rozumiany zespół miejski zajmuje powierzchnię $1830 \mathrm{~km}^{2}$ i skupia 17\% ludności kraju. Przyczyną tak wielkiej koncentracji jest scentralizowany system administracyjny, dzielący miasto na dwadzieścia departamentów, co wywołuje tzw. „fenomen paryski” - występowanie Paryża i „francuskiej pustyni”. Z tym ,,supermiastem nad Sekwaną” moga się równać jedynie aglomeracja lyońska i marsylska, liczące po około milionie mieszkańców. Podobną dysproporcję w rozmieszczeniu ludności, w Europie spotykamy tylko w Austrii i na Węgrzech.

Przypuszcza się, że niedługo co czwarty mieszkaniec Francji będzie

\footnotetext{
${ }^{5}$ Lutencja, miasto Parizjów na sekwańskiej wyspie Cite, w 52 roku została podbita przez Juliusza Cezara; w IV wieku cesarz Juliusz wzniósł tu łaźnie, arenę i forum.
} 
mieszkać w stolicy, nie dziwmy się zatem, że problemy Paryża uzyskały obecne rozmiary i rangę.

Królewski (od czasów Ludwika XIV), a potem rządowy centralizm nadały Paryżowi niezwykłe znaczenie i prestiż, które - choć z zastrzeżeniami, o jakich mowa będzie dalej - posiada do dzisiaj. Będąc stolicą państwa już za księcia Franków Chlodwiga I, Paryż stał się prawdziwą potega polityczna, administracyjną $i$ gospodarczą. Kolejni władcy rozbudowywali i upiększali stolicę ${ }^{6}$. Za Filipa Augusta wzniesiono Notre Dame i Luwr, za Ludwika Świętego - kaplicę Saint-Chapelle. W XVI i XVII wieku wybudowano Pałac Luksemburski, Hotel Inwalidów i Lambert, Obserwatorium. Rokoko przyniosło siedzibę prezydenta - Pałac Elizejski, zaś w drugiej połowie XVIII wieku w stylu Ludwika XVI zaprojektowano Panteon, gdzie spoczywają m. in.: Wolter, Rousseau, Hugo i Zola. Styl empire wzbogacił wygląd miasta o światynię sławy La Madeleine, gmach Giełdy, łuki triumfalne na placach de l'Etoile i du Carrousel oraz o kolumnę Wielkiej Armii z posagiem Napoleona na placu Vendome, odlaną z kul armatnich pochodzacych z bitwy spod Austerlitz. Historyzm i eklektyzm to przede wszystkim trzystumetrowy, metalowy symbol Paryża - wieża nazwana na cześć inżyniera Gustawa Eiffela. W rzeczywistości autorem projektu tej konstrukcji był Maurice Koechlin, pracownik przedsiębiorstwa Eiffela. Wieża waży 10,5 tys. ton, przy jej budowie zużyto 22,5 mln nitów. Posiada 16 filarów, 3 tarasy i 1671 stopni. Wzniesiono ja z okazji wystawy światowej w 1898 roku w fenomenalnie krótkim czasie nieco ponad dwóch lat. Początkowo wzbudzała wiele kontrowersji i wywoływała diametralnie różne opinie. Mawiano na przykład, że Maupassant odwiedzał restauracje na jednym z tarasów wieży tylko dlatego, że jej stamtąd nie było widać. Dzisiaj konstrukcja na Polu Marsowym stanowi architektoniczną wizytówkę miasta.

Nowoczesne budownictwo Paryża reprezentuja: Muzeum Sztuki Współczesnej, Hale Targowe, podziemne centrum handlowe Forum, gmach UNESCO, kompleks wystawowy im. G. Pompidou oraz dzielnica La Defense. Centrum Pompidou kojarzone bywa $\mathrm{z}$ rafineria lub fabryka, ponieważ jego twórcy, Piano i Rogers, pozostawili instalację elektryczną $i$ wentylacyjną oraz ruchome schody przypominające pełzającego węża, na zewnątrz budynku. La Defense zaś to dzielnica z metalu i szkła, powstała w latach 1956-1990 i ciagle rozbudowywana.

${ }^{6}$ Jedynie Karolingowie przenieśli stolicę kraju do Akwizgranu. 
Jej symbol to Wielki Łuk, zaprojektowany przez duńskiego architekta, Otto von Spreckelsena. Dzięki swej oryginalności, te dwa obiekty są chętniej odwiedzane przez turystów niż wieża Eiffela, co dowodzi, że od Paryża oczekuje się, poza tradycją i historią, także innowacji oraz awangardy.

Jak wspomniałam, we Francji występuje dominacja największego miasta - stolica rozwija się kosztem miast średnich, co jest możliwe dzięki względnej jednolitości politycznej i ekonomicznej kraju. Paryż najpełniej odzwierciedla kulturę i charakter całej Francji. Uzyskując prymat nad innymi, wiodące miasto stara się przyciagnnąc osoby najbardziej utalentowane $i$ przedsiębiorcze. Skupia więc Paryż ośrodki najwyższych władz państwowych, będąc jednocześnie siedzibą organizacji międzynarodowych: UNESCO, Biura Czasu, Biura Miar i Wag, Federacji Lotniczej. To olbrzymie centrum handlowo-usługowe koncentruje 17\% osób zatrudnionych w przemyśle i $23 \% \quad$ w usługach; połowa wszystkich francuskich przedsiębiorstw, 70\% towarzystw ubezpieczeniowych i 95\% banków ma tu swoje przedstawicielstwa. Główne sektory paryskiego przemysłu to produkcja: samochodów (Renault, Citroen, Pegueot), samolotów, przemysł poligraficzny, chemiczny, kosmetyczny, perfumeryjny ${ }^{7}$, spożywczy: młynarski i cukierniczy (ze słynnym, lekkim ciastem, liczącym nawet ponad tysiąc warstw).

Jest też Paryż prawdziwym centrum nauki, sztuki i kultury. W 1972 roku, po reformie średniowiecznej jeszcze Sorbony, wyodrębniono trzynaście uniwersytetów, na których w roku 1990 studiowało łącznie 307 tys. osób. Światowe znaczenie maja: College de France, Szkoła Nauk Politycznych, Instytut Pasteura, Instytut Wzornictwa Przemysłowego czy też Instytut Świata Arabskiego. Istnieje tu 97 muzeów (w tym Luwr, Sztuki Współczesnej, Muzeum Człowieka, d'Orsay, Picassa, Rodina), 300 galerii sztuki, 200 kabaretów (z najsłynniejszym Moulin Rouge), 93 teatry, 336 kin i założony w 1653 roku ogród zoobotaniczny. Nie zaskakuje więc olbrzymia popularność Paryża wśród francuskich i zagranicznych turystów, głównie Niemców, Holendrów i Brytyjczyków. Z $22 \mathrm{mln}$ \$ corocznych wpływów z turystyki, Paryż dostarcza pokaźnej ich części. W 1450 hotelach co roku przebywa około $2,5 \mathrm{mln}$ osób.

Okazuje się jednak, że paryska kultura i sztuka, jak całe zresztą miasto,

\footnotetext{
${ }^{7}$ Rozkwit francuskiej perfumerii datuje się na okres panowania Katarzyny Medycejskiej, zaś masowe wytwarzanie perfum rozpoczał w $1714 \mathrm{r}$. Farin produkcją wody kolońskiej.
} 
nie maja demokratycznego charakteru i nie realizuja zasady społecznego egalitaryzmu.

Zachował się, a może nawet utrwalił, podział Paryża na departamenty tradycyjnie kojarzone z luksusem bądź nędza. Paryż to miejsce o janusowym obliczu, gdzie dystansom przestrzennym towarzyszą różnice społeczne. Niwelacja rozbieżności poprzez tworzenie i rozpowszechnianiu mitu o szczęściu oraz zadowoleniu społeczeństwa konsumpcyjnego jest pozorna. Nadal funkcjonuje reguła pochodząca z czasów fin de siecle'u: zamożni na zachodzie, ubodzy na wschodzie miasta. Dzielnica Łacińska ciagle jest dzielnica studentów, Montparnasse i Montmartre ${ }^{8}$ - artystów, Marais rzemieślników, a Sentier - kupców. Do dzisiaj okręg 16. nazywany jest ”, burżuazyjnym", zaś okręgi: 13., 19. i 20. to departamenty robotnicze. Powyższa sytuacja wynika z kilkusetletniej prawidłowości, że wiek i ceny nieruchomości są odwrotnie proporcjonalne do odległości od centrum miasta. Chociaż istnieją wyjątki, jak luksusowa podmiejska dzielnica biurokracji - Parly 2 - regułę tę możemy uznać za powszechnie obowiązująca.

Niezwykle trudno jest przedstawić, opisać i poddać analizie rzeczywisty obraz Paryża, trzeba mu bowiem odebrać część magii i romantycznego uroku; wskazać, że choć wspaniały, Paryż zaczyna przypominać inne europejskie i światowe stolice. Należy podważyć zasadność podtrzymywanego myślenia grupowego, zburzyć stereotyp funkcjonujacy tak w świadomości obcokrajowców, jaki i samych paryżan. Ci ostatni, dumni ze swojego miasta, coraz bardziej oddalali się od prowincji, czyli wszystkiego, co Paryżem nie było. W rezultacie stolica stała się obca i niezrozumiała dla pozostałych Francuzów. Obecnie podejmowane są próby dekosmopolityzacji i decentralizacji Paryża w celu przywrócenia mu dawnej roli, jaką jest reprezentowanie całego państwa i narodu. Na efekty tych działań trzeba jednak poczekać.

Utożsamiany z niekwestionowanym pięknem, szykiem, elitarną kulturą $i$ sztuką, modą i gastronomia, współczesny Paryż coraz mniej przypomina ten dawny. Montparnasse i Montmartre, gdzie swoje pracownie mieli Utrillo, van Gogh czy Picasso, gdzie narodził się kubizm, fowizm i nadrealizm, zostały zdominowane przez tanią sztukę ulicy. Wielkich artystów zastapili portreciści-amatorzy i połykacze ognia. Od kilkudziesięciu lat podważa się

\footnotetext{
${ }^{8}$ To właśnie uliczki Montmartre'u przemierza Amelia Poulain z filmu Jeana-Paula Jeunet'a.
} 
również pozycję Paryża w dziedzinie mody. W roku 1980 „Observer” odmówił mu prawa do miana światowej stolicy krawiectwa, gdyż to właśnie w Londynie wylansowano długość mini, a następnie maxi. Rzeczywiście, Paryż staje się importerem, a nie eksporterem nowych trendów.

Rolę haute couture zaczęła pełnić pop-kultura z Mekką w Nowym Jorku, Mediolanie i Tokio. Paryż długo walczył z globalizacja i amerykanizacja, w znacznej mierze jednak uległ ich przemożnym wpływom. Już w latach 60tych i 70-tych paryżanie od rodzimej sztuki woleli Hair czy Jesus Christ Super Star. W pobliżu Łuku Triumfalnego znajdował się ekskluzywny pub Sir Winston Churchill oraz liczne bary z fast-foodami. W hipermarketach można kupić paczkowane francuskie ciasto czy perfumy. Coraz bardziej zasadne staje się pytanie, jakie już w 1964 r. sformułowal prof. Etiemble w książce pod tym samym tytułem: „Czy mówisz po frangielsku?”.

Przed Paryżem i jego mieszkańcami stoja liczne, a przy tym naglące problemy. Cztery kwestie wydają się szczególnie istotne, a mianowicie: komunikacja, praca, odpoczynek i rekreacja połączona z rozrywką. Pisma „Harakiri” i „L'Express” ujęy to lapidarnie: metro - boulot - tele - dodo, czyli „metro - robota - telewizor - spanko”. Bez watpienia jest to określenie hiperboliczne, wręcz groteskowe, faktem pozostaje jednak, że nawet krótki pobyt w Paryżu może być męczący. Przeludnienie (około 890 osób na km² przy średniej krajowej 105 osób), monstrualne korki, brak terenów zielonych (przeciętnie na mieszkańca przypada zaledwie $1 \mathrm{~m}^{2}$ zieleni) i niewysublimowana rozrywka przed ekranem telewizora lub komputera - to integralne elementy paryskiej rzeczywistości. Paryżanie usiłują więc, zwłaszcza w soboty i niedziele, choć na krótko zapomnieć o coraz mniej przyjaznym mieście.

Zakładając na wstępie, że ewolucja samego Paryża niewątpliwie zmieniła jego mieszkańców, przyjrzyjmy się efektom tej metamorfozy. Z pewnością paryżanie nadal łączą cechy typowo mieszczańskie, nawet nieco filisterskie, $z$ własnościami tradycyjnie ludowymi, chłopskimi?. Realizm, rozwaga, ostrożność i umiar znalazły więc specyficzne połączenie z idealizmem, fantazja, humorem, sentymentalnością oraz indywidualizmem. „Nerwowy paryżanin" nie jest może tak bezpośredni i jowialny jak przeciętny Francuz, charakteryzuje go precyzja wypowiedzi i przenikliwość umysłu, celuje w

${ }^{9}$ G. Dobiecki, Krótki kurs o wyjatkowości Francji, „Magazyn Rzeczpospolitej”, 12.07.2002, s. 23. 
trafnych ripostach, bywa ironiczny, lecz obce są mu wyrachowanie i cynizm.

Życzmy mu, aby takim pozostał, a Paryżowi - aby św. Genowefa, patronka miasta - nadal pobrzękiwała pękiem kluczy, przypiętym u pasa, którym otwiera przyszłość miastu i jego mieszkańcom. 